\title{
Survival of two strains of Phthorimaea operculella (Lepidoptera: Gelechiidae) reared on transgenic potatoes expressing a Bacillus thuringiensis crystal protein
}

\author{
Enrique Rico, Victoria Ballester, José Luis Ménsua* \\ Departament de Genètica, Universitat de Valencia, Dr.Moliner 50, 46100 Burjassot, Valencia, Spain
}

(Received 20 Novembre 1997, accepted 25 February 1998)

\begin{abstract}
Two populations of Phthorimaea operculella (Zeller), one of them presumed to be resistant to Dipel (a commercial preparation of Bacillus thuringiensis delta-endotoxins), and the other susceptible, were grown on four cultivars of potatoes, two of them a first generation of transgenic plants, expressing the Bacillus thuringiensis Cry $1 \mathrm{Ab}$ delta endotoxin protein, and the other two untransformed. The moth population which was reported to be resistant, proved to have less mortality than the susceptible one, but it was not really resistant to Cry $1 \mathrm{Ab}$. The transgenic potatoes were partially protected against the attack of the moth. The adult survival of the two strains of Phthorimaea operculella reared on transgenic potatoes was less than half their survival on untransformed potatoes, so that Cryl Ab expressing potato tubers proved to protect partially against attack of the moth. (O Inra/Elsevier, Paris.)
\end{abstract}

Phthorimaea operculella / Bacillus thuringiensis / transgenic potatoes / Cry1Ab

Résumé - Survie de deux souches de Phthorimaea operculella (Lepidoptera : Gelechiidae) élevées sur des pommes de terre transgéniques exprimant la protéine Cry1Ab de Bacillus thuringiensis. Deux populations de Phthorimaea operculella (Zeller), l'une supposée résistante au Dipel ${ }^{\mathrm{TM}}$ (une préparation commerciale de delta-endotoxines de Bacillus thuringiensis) et l'autre sensible, ont été cultivées sur quatre cultivars de pomme de terre, deux transgéniques de première génération, exprimant la protéine Cry1 Ab de Bacillus thuringiensis, et deux non transformés. La population de papillons considérée comme résistante a présenté une mortalité inférieure à celle de l'autre population, mais n'était pas vraiment résistante à Cry1 $\mathrm{Ab}$. Les pommes de terre transgéniques étaient en partie protégées d'une attaque de l'insecte. La survie au stade adulte des deux souches de Phthorimaea élevées sur les plantes transgéniques était au moins deux fois inférieure à celle constatée sur les plantes non transformées. Il en résulte que les pommes de terre exprimant le gène cry $1 \mathrm{Ab}$ sont partiellement protégées des attaques du papillon. (@ Inra/Elsevier, Paris.)

Phthorimaea operculella / Bacillus thuringiensis / pommes de terre transgéniques / Cry1Ab

Communicated by Nicolás Jouve (Madrid)

* Correspondence and reprints

E-mail: jose.luis.mensua@uv.es 


\section{INTRODUCTION}

An application of genetic engineering to crop protection has been the production of plants expressing delta-endotoxins (insecticidal crystal proteins) from Bacillus thuringiensis [11, 13]. Bacillus thuringiensis produces diferent kinds of proteins which are toxic and highly specific to some lepidopteran, coleopteran and dipteran species. These toxic proteins are produced during bacterium sporulation. Commercial preparations of sporulated Bt cultures have been used for more than 25 years as biological insecticides. Genes encoding crystal proteins have been cloned and engineered into plants in order to protect such plants from insect attack. The performance of some of these transgenic plants, such as tobacco (Nicotiana tabacum) [11, 14], rice (Oryza sativa) [6], potato (Solanum tuberosum) [1, 2, 8, 13], has been evaluated in the laboratory and in the field.

The potato tuber moth, Phthorimaea operculella (Zeller), is one of the most important pests of potato in warm-temperate and tropical regions [7]. Larvae mine leaves and tubers, causing losses higher than $80 \%$ of the harvest, despite use of chemical insecticides. Resistance in Phthorimaea operculella populations to insecticides is one of the reasons that account for control failures. In recent reviews on insect resistance to Bacillus thuringiensis $[5,9,15]$ no reference to Phthorimaea operculella was made, indicating that no cases of resistance to this bioinsecticide have been reported in this insect species to date. Therefore, monitoring field populations of Phthorimaea operculella for resistance to Bacillus thuringiensis is of paramount importance for the future of Bacillus thuringiensis transformed potato plants [8].

Our objectives are to determine in laboratory experiments the toxicity of tubers transformed with a Cry1Ab gene [8] for Phthorimaea operculella, and to determine whether a Peruvian population of the moth, reported to be resistant to Cry $1 \mathrm{Ab}$, one of the crystal proteins present in Dipel (a commercial preparation of Bacillus thuringiensis) and toxic against susceptible populations of Phthorimaea operculella, is resistant to CryIA(b).

\section{MATERIALS AND METHODS}

\subsection{Origin of lines}

Transgenic potato plants expressing the Bacillus thuringiensis Cryl Ab gene were obtained from Plant Genetics Systems (Gent, Belgium) [8] after multiplication by Germicopa (Quimper, France). Germicopa supplied two 'Yesmina' cultivars of transformed tubers containing a wild-type Cry $1 \mathrm{Ab}$ gene. The quantities of toxin expressed by these two cultivars were $24 \mathrm{ng}$ Cry $1 \mathrm{Ab} / \mathrm{mg}$ total protein for PDS20.2 and $15 \mathrm{ng}$ Cry $1 \mathrm{Ab} / \mathrm{mg}$ for PDS20.3 (M. Peferoen, pers. comm.). Two untransformed cultivars of tubers, Yesmina and a local one, called Jerla, were used as control lines. Colonies of Phthorimaea operculella used in these experiments were derived from insects supplied by Plant Genetics Systems. One strain (R-strain) was collected from a storage treated with Dipel in the Amazonic region of Peru in 1989. Because control of the moth pest was not attained, the population was suspected to be resistant to Dipel (M. Peferoen, pers. comm.). The other strain was obtained from the University of California at Berkeley in the 1940s (Sstrain) and it was susceptible to Bacillus thuringiensis delta-endotoxins. Both strains were mantained on tubers at $25 \pm 2{ }^{\circ} \mathrm{C}$ and $80 \pm 10 \% \mathrm{RH}$, with a $16 \mathrm{~h} / 8 \mathrm{~h}$ (L/D) photoperiod.

\subsection{Survival experiment}

A factorial design was made. Eggs were collected in waxed paper placed inside population cages. One hundred to one hundred and fifty eggs from each strain of Phthorimaea operculella were placed on $1 \mathrm{~kg}$ of each of the four cultivars of potatoes in three replicates. Potato tubers were punctured with nails to facilitate the larvae entrance. Punctured potatoes were put into cubes that had at their bottom a grating covered with paper that was taken out 4 or 5 days after eggs added. This cube was put inside another one which contained a cape of 3 $\mathrm{cm}$ of sterilized beach sand and a support. Every 2 days pupae were collected and put into a case with a grating. Emerging adults were also collected and counted. The experiment was repeated with a 6 month interval. The adult survival of Phthorimaea operculella from egg to adult (egg number deposited/adult number collected) of the two strains in the four cultivars of potatoes and in 
the two experiments (A and B) were recorded and compared with an ANOVA.

\section{RESULTS AND DISCUSSION}

The adult surviyal of the S- and R-strains reared on different potato cultivars for the experiments $\mathrm{A}$ and $\mathrm{B}$ are presented in table $I$. The mean values \pm S.E. of the main effects (strains $S$ and $R$ of Phthorimaea operculella, cultivars of potatoes, and experiments) are presented in table II. The survival of the R-strain was higher than that observed with the S-strain in the four cultivars of potatoes. A clear difference in Phthorimaea operculella survival between untransformed tubers and transgenic ones was also observed. The differences in survival between experiments were also significant.

The results of ANOVA are presented in table III. There are significant differences in the main effects. The overall survival of the R-strain $(34.3 \%)$ was significantly higher than the S-strain (22.1\%) (table II and III). Among potato cultivars the survival of Phthorimaea operculella (S- and Rstrains) in the untransformed potatoes was around $40 \%$, and only around $20 \%$ in the transgenic potatoes (table II). This difference was highly significant (table III). There were significant differences between the two cultivars of transgenic tubers, but only at the level of $5 \%$. There were no differences at all between untransformed tubers. Between experiments $\mathrm{A}$ and $\mathrm{B}$ the survival in the two experiments was different, being significantly higher in the second one $(30.8 \%$ versus $25.6 \%$ ) (table II and III), performed 6 months later. In contrast with the highly significant differences in the main effects, there were no significative interactions (table III).

The differences in survival between experiments $\mathrm{A}$ and $\mathrm{B}$ are mainly (if not solely) due to the differences in survival in the transgenic tubers (table III). The transgenic tubers used in our experiments

Table II. Mean survival \pm S.E. in the main effects: strains, cultivars of potatoes and experiments of $P$. operculella.

\begin{tabular}{lc}
\hline Main effects & Survival (Mean \pm S.E.) \\
\hline Strain S & $22.1 \pm 2.5$ \\
Strain R & $34.3 \pm 2.9$ \\
Jerla & $39.9 \pm 2.8$ \\
Yesmine & $39.5 \pm 3.3$ \\
PDS 20.3 & $19.1 \pm 1.5$ \\
PDS 20.2 & $14.3 \pm 2.4$ \\
Experiment A & $25.6 \pm 2.9$ \\
Experiment B & $30.8 \pm 2.9$ \\
\hline
\end{tabular}

Each value represents the mean of 24 replicates (experiments and strains) or of 12 replicates (transgenic and non-transgenic cultivars of potatoes).

Table I. Mean survival \pm S.E. of two strains of $P$. operculella reared on four cultivars of potatoes in two experiments performed 6 months apart.

\begin{tabular}{lccc}
\hline & & & Adult Survival \\
& Potato cultivars & Experiment A & Experiment B \\
\hline Strain S & Jerla & $28.3 \pm 1.9$ & $36.4 \pm 3.4$ \\
& Yesmine & $30.8 \pm 10.1$ & $32.4 \pm 6.7$ \\
& PDS 20.3 & $12.5 \pm 4.7$ & $18.2 \pm 0.8$ \\
Strain R & PDS 20.2 & $4.6 \pm 2.4$ & $13.5 \pm 7.2$ \\
& Jerla & $45.0 \pm 4.9$ & $49.8 \pm 6.6$ \\
& Yesmine & $44.9 \pm 4.5$ & $49.8 \pm 9.4$ \\
& PDS 20.3 & $20.6 \pm 0.7$ & $24.9 \pm 0.7$ \\
& PDS 20.2 & $17.7 \pm 5.5$ & $21.4 \pm 3.4$
\end{tabular}

Each value is the mean of three replicates. 
Table III. ANOVA of the survival of two populations of Phthorimaea operculella reared on four potato cultivars in two experiments performed 6 month apart.

\begin{tabular}{lccccc}
\hline Variation sources & d.f. & SS & MS & F & P \\
\hline Main Effects & & & & & $* * *$ \\
Insects (S- and R-strains) & 1 & 854.1 & 854.1 & 42.6 & $* * *$ \\
Potatoes (Cultivars) & 3 & 2979.3 & 993.1 & 49.5 & $* * *$ \\
$\quad$ Untrans versus Transgenic & 1 & 2863.6 & 2863.6 & 142.8 & ns \\
$\quad$ Yesmine versus Jerla & 1 & 0.6 & 0.6 & 0.03 & $*$ * \\
$\quad$ PDS20.2 versus PDS20.3 & 1 & 115.1 & 115.1 & 5.7 & $\mathrm{~ns}$ \\
Experiments (A and B) & 1 & 183.3 & 183.3 & & $\mathrm{~ns}$ \\
Interactions & & & & 0.5 & $\mathrm{~ns}$ \\
Insects/Potatoes & 3 & 1.2 & 10.4 & 0.7 & $\mathrm{~ns}$ \\
Insects/Experiments & 1 & 14.5 & 14.5 & 0.4 & \\
Potatoes/Experiments & 3 & 22.5 & 7.5 & & \\
Insects/Potat./Exper. & 3 & 22.5 & 7.5 & & \\
Error & 32 & 641.7 & 20.1 & & \\
Total & 47 & 4749.1 & & &
\end{tabular}

ns, not significant. $* P=0.05 ; * * P<0.01 ; * * * P<0.0001$.

did not protect the tubers completly from the damage by the larvae. This allowed us to detect differences between experiments $\mathrm{A}$ an $\mathrm{B}$ performed 6 months apart. In other experiments, Jansens et al. (cited by Van Rie et al., [13]) analysed transgenic tubers [transformed also with CryIA(b)] harvested and stored for several months, and found that larval development of Phthorimaea operculella was completely inhibited. Nevertheless, the level of crystal proteins produced by their lines was at least two times higher than in our lines. A plausible explanation for our data is that the crystal protein accumulated into the tuber cells is slowly degrading with time. However, when protection against Phthorimaea is sufficiently high (as in Jansens et al. experiments), the effect of a possible crystal protein degradation with time is not detected.

The differences in survival of the $R$ - and $S$ strains shows that the R-strain has a better survival than the $\mathrm{S}$ strain, not only on transgenic tubers but also in non-transgenic ones. The fact that there is no interaction between main effects (table III) suggest that the $\mathrm{R}$-strain is not a resistant strain. Simply, it has a better fitness than the S-strain. Escriche et al. [3] working with the same two strains of Phthorimaea operculella, found no differences either in the binding affinity of Cry $1 \mathrm{Ab}$ and CrylC to specific sites in brush border membrane vesicles or in the concentration of binding sites. All of these results suggest that the higher viability of the $\mathrm{R}$-strain does not depend on changes in midgut receptors that would protect the insect against Bacillus thuringiensis crystal protein as it was found in other cases $[4,10,12]$.

The two transgenic cultivars of potatoes are partially protected against attack by moth, reducing the survival of both strains of Phthorimaea operculella to $50 \%$ or less, compared to the control cultivars. Moreover, as expected, there is an inverse correlation between the quantity of Cry $1 \mathrm{Ab}$ expressed by the transgenic plants and the survival of Phthorimaea operculella. PDS20.2 expresses $24 \mathrm{ng}$ of Cry1 Ab per mg of total protein and the Phthorimaea operculella survival was $14.3 \pm 2.4$, whereas PDS20.3 expresses $15 \mathrm{ng} / \mathrm{mg}$ and the survival was $19.1 \pm 1.5$. This difference in survival was found to be significant $(P<0.05)$ (see table III).

These experiments confirm the effectiveness of this first generation of transgenic potatoes. After 
these experiments were performed, a second generation of transgenic potatoes was obtained by Plant Genetic System with a modified Cryl Ab gene, producing a higher concentration of CrylAb deltaendotoxin [13], so we suppose these potatoes will be more effective against moth attack but it will have to be proved at laboratory.

Acknowledgments: We thank Juan Ferre for helpful discussion and suggestions. We thank also Eric Bonnel, from Germicopa (France), who provided us the two transgenic and one of the untransformed tubers; Marnix Peferoen, from Plant Genetic System, who provided us the two populations of Phthorimaea operculella. This research was funded by the European Comunity through AGRE 0003(GDF).

\section{REFERENCES}

[1] Cheng J., Bolyard M. G., Saxena R. C., Sticklen M. B., Production of insect resistant potato by genetic transformation with a d-endotoxin gene from Bacillus thuringiensis var kurstaki, Plant Sci. 81 (1992) 83-91.

[2] Ebora R.V., Ebora M. M., Sticklen M. B., Transgenic Potato Expressing the Bacillus thuringiensis CrylA(c) Gene Effects on the Survival and Food Consumption of Phthorimaea operculella (Lepidoptera: Gelechiidae) and Ostrinia nubilalis (Lepidoptera: Noctuidae), J. Econ. Entomol. 87 (1994) 1122-1127.

[3] Escriche B., Martínez-Ramírez A. C., Real M. D., Silva F. J., Ferre J., Occurrence of three different binding sites for Bacillus thuringiensis delta-endotoxins in the midgut brush border membrane of the potato tuber moth, Phthorimaea operculella (Zeller), Arch. Insect Biochem. Phys. 26 (1994) 315-327.

[4] Ferré J., Real M. D., Van Rie J., Jansens S., Peferoen M., Resistance to the Bacillus thuringiensis bioinsenticide in a field population of Plutella xylostella is due to a change in a midgut membrane receptor, Proc. Natl. Acad. Sci. 88 (1991) 5119-5123.

[5] Ferré J., Escriche B., Bel Y., Van Rie J., Biochemistry and genetics of insect resistance to
Bacillus thuringiensis insecticial crystal proteins, FEMS Microbiol. Lett. 132 (1995) 1-7.

[6] Fujimoto H., Itoh K., Yamamoto M., Kyozuka J., Shimamoto K., Insect resistant rice generated by introduction of a modified delta-endotoxin gene of Bacillus thuringiensis, Bio/Technology 11 (1993) 1151-1155.

[7] Hill D. S., Agricultural Insect Pests of Temperate Regions and their Control, Cambrigde University Press, Cambridge, 1987.

[8] Peferoen M., Jansens S., Reynaerts A., Leemans J., Potato plants with engineered resistance against insect attack, in: Vayda M.E., Park W.C. (Eds.), Molecular and Cellular Biology of the Potato, CAB International, Wallingford, 1990, pp. 193-204.

[9] Tabashnik B. E., Evolution of resistance to Bacillus thuringiensis, Annu. Rev. Entomol. 39 (1994) 47-79.

[10] Tabashnik B. E., Finson N., Johnson M. W., Moar W. J., Resistance to Toxins from Bacillus thuringiensis subsp kurstaki Causes Minimal CrossResistance to $B$ thuringiensis subsp aizawai in the Diamondback Moth (Lepidoptera: Plutellidae), Appl. Environ. Microbiol. 59 (1993) 1332-1335.

[11] Vaeck M., Reynaerts A., Höfte H., Jansens S., Beuckeleer M. De, Dean C., Zabeau M., Van Montagu M., Leemans J., Transgenic plants protected from insect attack, Nature 327 (1987) 33-37.

[12] Van Rie J., McGaughey W. H., Johnson D. E., Barnett B. D., Van Mellaert H., Mechanism of insect resistance to the microbial insecticide Bacillus thuringiensis, Science 247 (1990) 72-74.

[13] Van Rie J., Jansens S., Reynaerts A., Engineered resistance against potato tuber moth, in: Zehnder G.W., Powelson M.L., Jansson R.K., Raman K.V. (Eds.), Advances in Potato Pest Biology and Management, 1994, pp. 499-508.

[14] Warren G. W., Carozzi N. B., Desai N., Koziel M. G., Field evaluation of transgenic tobacco containing a Bacillus thuringiensis insecticidal protein gene, J. Econ. Entomol. 85 (1992) 1651-1659.

[15] Whalon M.E., McGaughey W. H., Insect resistance to Bacillus thuringiensis, in: Kim L., (Ed.), Advanced Engineered Pesticides 1993, Marcel Dekker, New York, 1993, pp. 215-232. 